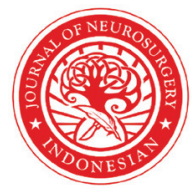

Indonesian Journal of Neurosurgery

\title{
Extraction of gunshot corpus allienum in upper cervical spine with transoral approach: A case report
}

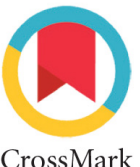

\author{
Novan Krisno Adji ${ }^{1,2 *}$, Muhammad Yuda Nugraha²
}

${ }^{1}$ Neurosurgery Department, dr. Soebandi Regional Hospital, Jember, Indonesia ${ }^{2}$ Faculty of Medicine, University of Jember, Indonesia

*Corresponding to :

Novan Krisno Adji; Neurosurgery

Department, dr. Soebandi Regional

Hospital, Jember, Indonesia;

soebandi@pdpersi.co.id/

sistemrsddrsoebandi@gmail.com

\section{ABSTRACT}

Introduction: Penetrating trauma that caused by gunshot injuries have been reported about $17-21 \%$ of all spinal cord injuries. Transoral approach may facilitate accessing the lumens and sites such as upper cervical spine with minimally invasive surgical exposure. Here, we present an interesting case of removal a bullet in the cervical spine with new method. Case Presentation: A 53-year-old man who underwent a gunshot in the maxillary region of the face. A CT scan of head and neck showed that a metallic foreign body located in corpus vertebrae as high as C1-C2. The bullets in this patient were removed under the minimal invasive surgery through transoral approach. The patients were discharged without neurological deficit.

Conclusion: The presented transoral approach can be used as minimal invasive surgery method to extract corpus allienum in upper cervical spinal region without spinal cord tissue damage.
Received: 2020-05-11

Accepted: 2021-03-13

Published: 2021-04-22
Keywords: Cervical spine, Corpus allienum, Gunshot injury, Transoral approach

Cite This Article: Adji, N.K., Nugraha, M.Y. 2021. Extraction of Gunshot Corpus Allienum in Upper Cervical Spine with Transoral Approach: A Case Report. Indonesian Journal of Neurosurgery 4(1): 1-3. D0l: 10.15562/ijn.v4i1.129

\section{INTRODUCTION}

Spinal cord injury (SCI) occurs after traumatic injury with range of incidences are 12.1 to 57.8 cases per million annually both penetrating or non-penetrating. ${ }^{1}$ The third most causes of spinal cord injury are motor accident, falling from heights accident and penetrating trauma. ${ }^{2}$ Common case that causes penetrating trauma is stabbing injury with knives, missile, or gunshot where usually occurs in high crime rates area. And gunshot injuries have been reported as penetrating trauma that causes SCI about $17-21 \%{ }^{3}$ Cervical spine trauma incidence is 45$75 \%$ compared with the others location of traumatic SCI. ${ }^{4}$ Cervical spine trauma is potentially causes long-term disability because this structure consists of complex neurovascular structures. Thus, operating through this region represents a challenge. ${ }^{5}$

\section{CASE PRESENTATION}

A 53-year-old man was brought to the emergency room (ER) of dr. Soebandi Regional Hospital with severe headache, irregular breathing and weakness in both legs after getting gunshot in the maxillary region of the face. The patient was taken anterior-posterior and lateral cervical photographs (Figure 1) at a Level C Hospital in the Kalisat region before being referred to dr. Soebandi General Hospital.

Based on anamnesis, the patient complained severe headache with behavioral pain scale 7-9, while on physical examination the vital signs were normal but there was thoracoabdominal respiration. In the inspection of neck and spine region, there was normal without any sign of inflammation or cerebrospinal

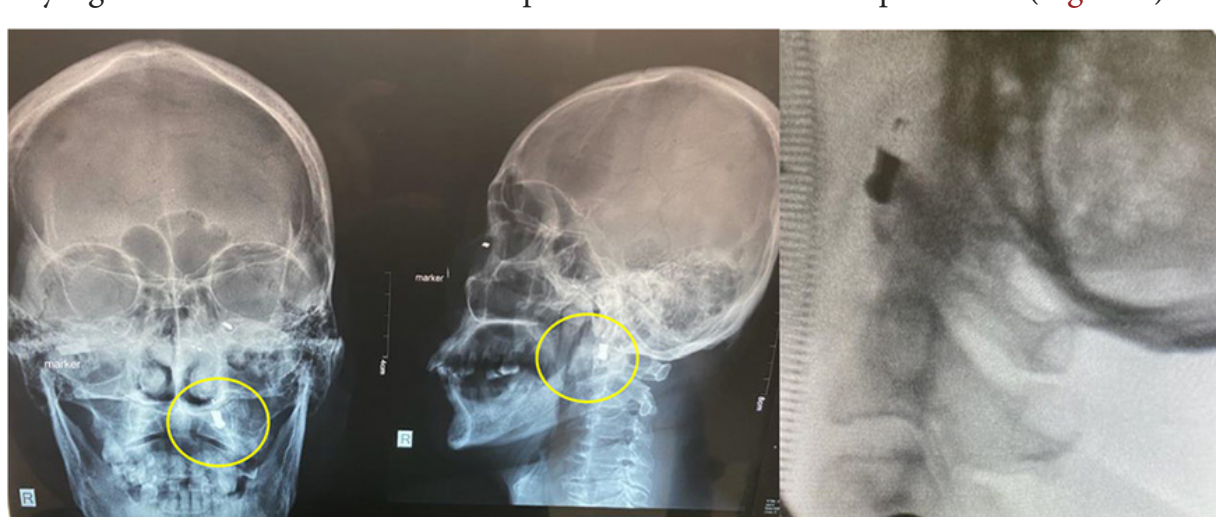

Figure 1. Anterior-posterior and lateral cervical photographs. Corpus allienum found in the upper cervical region (yellow circle) fluid fistula. The patient showed full of consciousness and intact cranial nerve function during neurological examination, but there were lower paraparesis. After a thorough and stable evaluation, the patient was given prophylaxis as an initial treatment in the ER with ceftazidime and tectagram to prevent probably infection. Then the patient underwent a head and neck CT scan in the ER. Based on CT scan evaluation, there was a corpus alienum with a metal density in anterior of corpus vertebrae as high as $\mathrm{C} 1-\mathrm{C} 2$ without abnormalities in spinal cord (Figure 2). 


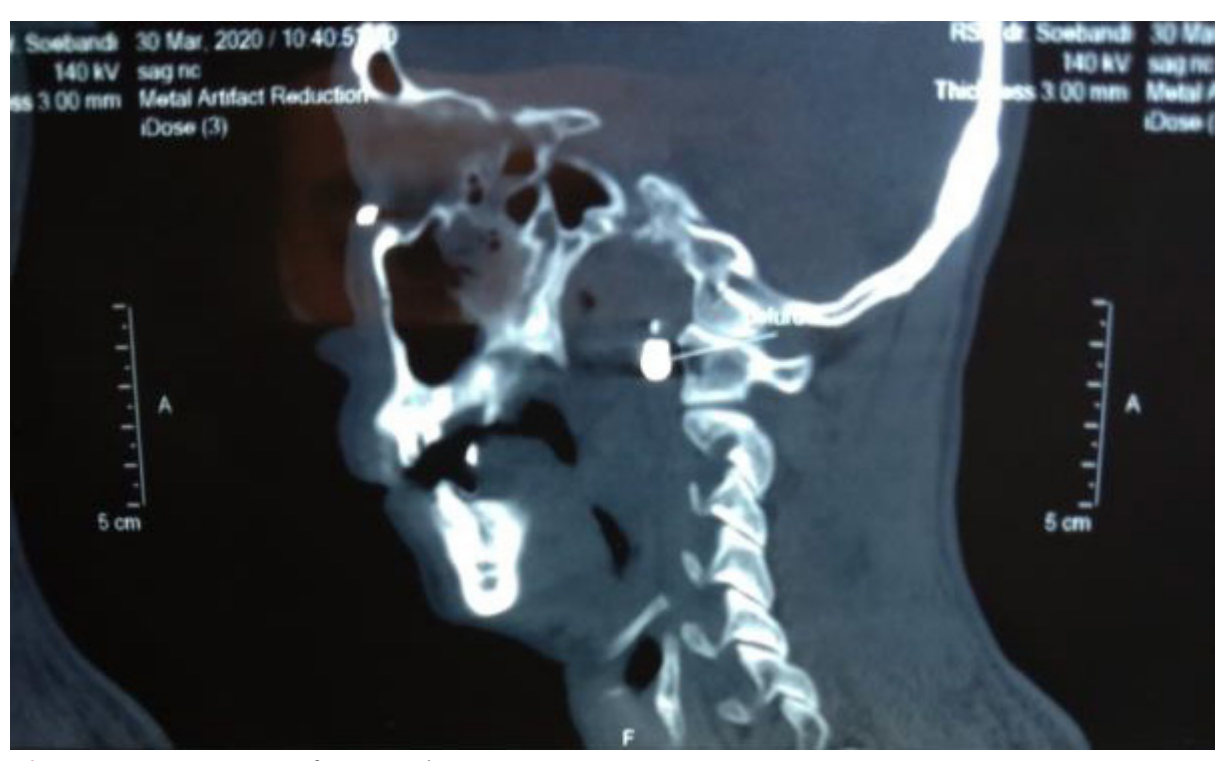

Figure 2. CT scan of cervical region

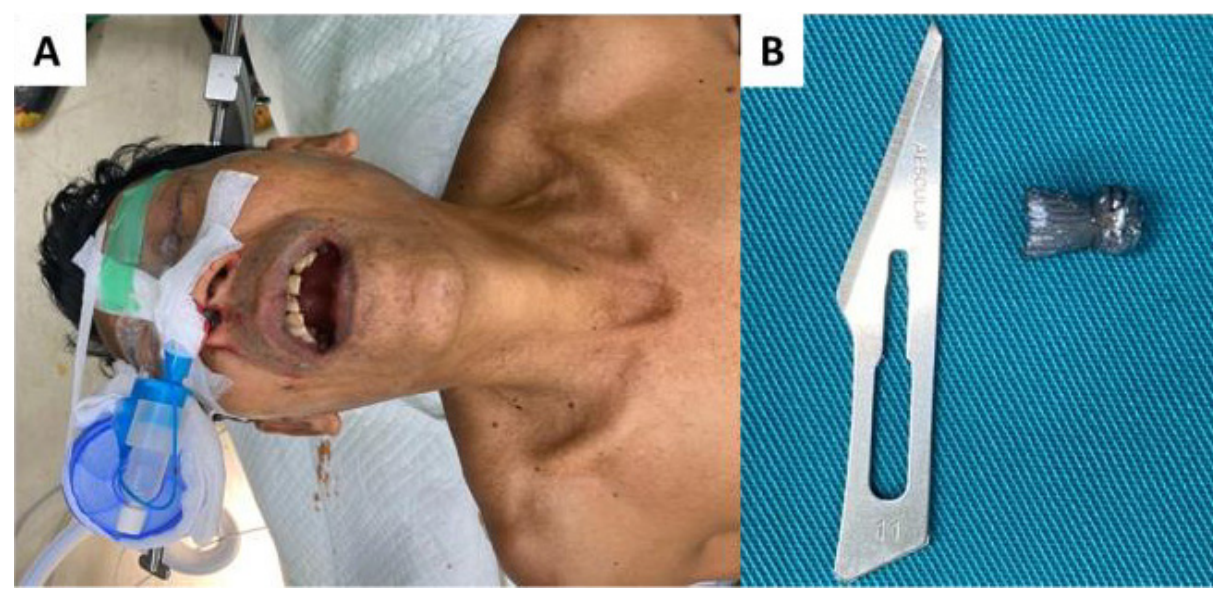

Figure 3. (A) Transoral approach surgery patient's position. (B) Corpus allienum bullet after extraction

Then the patient planned surgery to extract the corpus allienum through transoral approach (Figure 3A). Corpus allienum that had been obtained is a bullet where located at the anterior arcus of vertebrae C1 during surgery. After the bullet was removed (Figure 3B), the spinal cord was decompressed and pulsated well. The patient was treated post surgery in the intensive care unit for 48 hours without the aid of a ventilator. Three days post surgery the patient had an improvement in his motor function on both lower extremities. The bladder and bowel functions had also improved as the patient could feel and hold urine. The patient was discharged on day 4 postoperatively with full of consciousness and no neurological deficit.

\section{DISCUSSION}

Gunshot injury to the spine causes tissue damage in gunshot injury that depends on velocity, mass, shape, and composition of the bullet material that determine the severity of the trauma. Generally, tissue damage causes in the surrounding tissue or secondary damage that creates cavitation process of the tissue by generating shock waves. ${ }^{6}$ In this case, the type of bullet that was found is civilian weapon, wind riffle bullet, which is low velocity, small, blunt and metal composed by iron. This type of bullet causes a direct injury with low comorbidity incidence.

Initial treatment of patients with gunshot injury should attent systemic stabilization, then a detail history including mechanisms of trauma, type of weapon, distance, and the number of shots should be recorded as the protocol of basic trauma resuscitation in ATLS. To determine the level of SCI can be found on neurological examination. The severity of the neurological deficit increases the risk of death in patient. ${ }^{7}$ Wounds should be identified as an entry wound and exit wound and recorded in which region. The wounds should also be inspected for any leakage of cerebrospinal fluid, bullets, and another corpus alienum. Removing the corpus alienum in the ER should be avoided because it possibles severe bleeding. Therefore extraction of the corpus alienum should be performed in the operating room. ${ }^{8}$

The treatment strategies remain being debated. In 1990, Kupcha et al suggested an observation rather than surgical removal of retained bullet fragments in the cervical spine of the patients because it does not increase the risk of infection while surgical management might result in secondary complications. ${ }^{9,10}$ However, it should be noted the possibility that the bullets migrate from their initial locations. The migration of the bullets may easily damage the surrounding structures which are a small body part with several vital contents including important nerves and blood vessels. Therefore surgical is necessary to remove the corpus allienum, but it should be noted that there is high possibility of neurovascular injury. ${ }^{11,12}$ Surgical procedure to remove a corpus allienum should performs an appropriate techniques with minimal complication. ${ }^{13}$ In this case, we used transoral approach to extract the corpus allienum.

Transoral approach can access the craniovertebral junction area as anterior arch of C1.14 Transoral approach technique was uncommon used to remove corpus allienum from upper cervical spine region. The advantage of this approach is minimal damage in surrounding tissues, thus decreasing surgical complications. And then there have been significant improvements in the efficacy and safety of the transoral approach over the past several decades. Depending on the location of the bullet in the upper cervical region, transoral approaches were feasible as alternative safety technique. ${ }^{15}$ 


\section{CONCLUSION}

The presented transoral approach can be used as method to extract corpus allienum in upper cervical spinal region without spinal cord tissue damage. This approach can be used to safely and effectively expose the upper cervical spine anatomical structure and has advantages of direct access, relatively simple operation, short operative time, quick recovery, a reliable curative effect, and few complications.

\section{CONFLICT OF INTEREST}

There is no conflict of interest related to the materials or methods used in this study.

\section{FUNDING}

This article received no specific funding from any funding agency in the public, commercial, or not-for-profit sectors.

\section{AUTHOR'S CONTRIBUTIONS}

Authors took part in the design of the study, contributed to data collection, participated in writing the manuscript and all agree to accept equal responsibility for accuracy of the contents of this article.

\section{REFERENCES}

1. Amps J, Steinmetz MP, Krishnaney AA et al. Surgical Treatment of Penetrating Wound of the Spine. Neurosurgical Operative Atlas: Spine and Peripheral Nerves, 3rd edition, Tiemes, 2016. ISBN: 9781604068986.

2. Chen Y, Tang Y, Vogel LC, Devivo MJ. Causes of spinal cord injury. Top Spinal Cord Inj Rehabil. 2013 Winter;19(1):1-8. DOI: 10.1310/sci1901-1

3. Patil R, Jaiswal G, Gupta TK. Gunshot wound causing complete spinal cord injury without mechanical violation of spinal axis: Case report with review of literature. J Craniovertebr Junction Spine. 2015 Oct-Dec; 6(4): 149-57. DOI: $10.4103 / 0974-8237.167855$

4. Torretti JA, Sengupta DK. Cervical spine trauma. Indian J Orthop. 2007 Oct;41(4):25567. DOI: 10.4103/0019-5413.36985

5. Snell, R.S. The spinal cord and the ascending and descending tracts. Clinical Neuroanatomy. Lippincott Williams \& Wilkins. 2010. ISBN 978-0-7817-9427-5.

6. Sidhu GS, Ghag A, Prokuski V et al. Civilian gunshot injuries of the spinal cord: A systematic review of the current literature. Clin Orthop Relat Res. 2013; 471: 3945-55. DOI: 10.1007/ s11999-013-2901-2

7. Brasel S, Karen S, Ronald M et al. Advanced Trauma Life Support for Doctors. American College of Surgeons, Chicago. 1997. p27

8. Azevedo-Filho HR, Martins C, Carneiro-Filho GS et al. Gunshot wounds to the spine: Study of 246 patients. Neurosurg Q. 2001; 267: 14-21. DOI: $10.1590 /$ S0004-282X2001000400034

9. Kupcha PC, An HS, Cotler JM. Gunshot wounds to the cervical spine. Spine 1990;1510:1058-63.
DOI: $10.1097 / 00007632-199015100-00014$

10. Velmahos G, Demetriades D. Gunshot wounds of the spine: should retained bullets be removed to prevent infection?. Ann R Coll Surg Engl 1994;762:85-7. PMCID: PMC2502214

11. Wang J, Ye CY, Zhu MY, et al. Gunshot-caused facial injury combined with lower cervical spine injury: a case report. West Indian Med J 2014;634:378-81. DOI: 10.7727/wimi.2013.260

12. Walter T, Schwabe P, Schaser KD, et al. Positive outcome after a small-caliber gunshot fracture of the upper cervical spine without neurovascular damage. Polish J Radiol 2016;81:134-7. DOI: 10.12659/PJR.895529

13. Secer M, Ulutas M, Yayla E, et al. Upper cervical spinal cord gunshot injury without bone destruction. Int J Surg Case Rep 2014;53:14951. DOI: 10.1016/j.ijscr.2014.01.009

14. Li Q, Jiang Z, Zhuo X, Zhang X. Endoscopic removal of bullets from the cranial ridge junction region via transoral and transnasal approaches. Medicine 2016; 95:24. DOI: 10.1097/MD.0000000000003918

15. Shriver MF, Kshettry VR, Sindwani R, et al. Transoral and transnasal odontoidectomy complications: a systematic review and metaanalysis. Clin Neurol Neurosurg 2016;148:1219. DOI: 10.1016/j.clineuro.2016.07.019

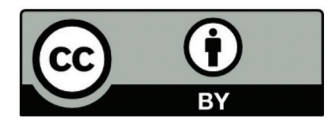

This work is licensed under a Creative Commons Attribution 